\title{
Chromohalobacter nigrandesensis sp. nov., a moderately halophilic, Gram-negative bacterium isolated from Lake Tebenquiche on the Atacama Saltern, Chile
}

\author{
Bernardo Prado, ${ }^{1,2}$ Catherine Lizama, ${ }^{1,3}$ Margarita Aguilera, ${ }^{1}$ \\ Alberto Ramos-Cormenzana, ${ }^{1}$ Susana Fuentes, ${ }^{1}$ Victoriano Campos ${ }^{4}$ \\ and Mercedes Monteoliva-Sánchez ${ }^{1}$
}

\begin{abstract}
Correspondence Mercedes Monteoliva-Sánchez mmonteol@ugr.es
\end{abstract}

\author{
${ }^{1}$ Department of Microbiology, Faculty of Pharmacy, University of Granada, Campus Universitario \\ de Cartuja s/n, 18071 Granada, Spain \\ 'Laboratory of Microbiology, 'Universidad Técnica Federico Santa María, Sede Viña del Mar', \\ Viña del Mar, Chile \\ ${ }^{3}$ Department of Medical Technology, 'Facultad de Ciencias de la Salud, Universidad de \\ Antofagasta', Av. Jaime Guzmán s/n, Antofagasta, Chile \\ ${ }^{4}$ Laboratory of Environmental Microbiology, Catholic University of Valparaiso, Valparaíso, Chile
}

Moderately halophilic micro-organisms have been the subject of a variety of taxonomic and ecological studies (Ventosa et al., 1998; Oren, 2002). Moderate halophiles grow best at $\mathrm{NaCl}$ concentrations between 0.5 and $2.5 \mathrm{M}$. They represent a very heterogeneous group distributed extensively in high salinity zones (Rodriguez-Valera, 1988; Kaye et al., 2004). The different branches of the phylum Proteobacteria have various halophilic representatives with close relatives that are non-halophilic. Among the bacterial families that form part of the largest subgroup, the class Gammaproteobacteria, the family Halomonadaceae is characterized as being represented by several halophilic, halotolerant and non-halophilic species that belong to different genera. Halomonas is the largest genus in this family, containing more than 30 species,

Published online ahead of print on 2 December 2005 as DOI 10.1099/ ijs.0.63983-0.

The GenBank/EMBL/DDBJ accession number for the 16S rRNA gene sequence of strain LTS-4N ${ }^{\top}$ is AJ277205. followed by the genus Chromohalobacter, which presently has five species. Cobetia marina, Carnimonas nigrificans and Zymobacter palmae are also included in the family Halomonadaceae.

'Chromobacterium marismortui', isolated from the Dead Sea, was originally described as a moderately halophilic bacterium by Elazari-Volcani (1940). Later, Ventosa et al. (1989) reclassified 'Chromobacterium marismortui' as Chromohalobacter marismortui. Other species were subsequently placed in the genus Chromohalobacter, as Chromohalobacter canadensis and Chromohalobacter israelensis (Arahal et al., 2001a), Chromohalobacter salexigens (Arahal et al., 2001b) and the recently described species Chromohalobacter sarecensis (Quillaguamán et al., 2004). All these species are moderately halophilic, aerobic, motile, Gram-negative, heterotrophic rods. The species of the genus Chromohalobacter form a monophyletic group within the family Halomonadaceae (Arahal et al., 2002). 
In the present study, the characteristics of strain LTS- $4 \mathrm{~N}^{\mathrm{T}}$, which was selected as a representative from a group of 52 moderately halophilic strains isolated from a hypersaline lake on Atacama Saltern, Chile, were examined in detail and strain LTS- $4 \mathrm{~N}^{\mathrm{T}}$ was compared with other halophilic, Gram-negative rods. Based on its morphological and physiological characteristics, as well as on its phylogenetic position determined by $16 \mathrm{~S}$ rRNA gene sequence analysis and DNA-DNA relatedness data, strain LTS- $4 \mathrm{~N}^{\mathrm{T}}$ should be classified as representing a novel species within the genus Chromohalobacter.

The 52 strains used in this study were moderately halophilic, Gram-negative, motile, rod-shaped bacteria that were isolated in 1991 from sediments of the hypersaline Lake Tebenquiche at the Atacama Saltern, Chile. The following halophilic, Gram-negative micro-organisms were used as reference strains: C. marismortui ATCC $17056^{\mathrm{T}}$, C. salexigens CECT $5384^{\mathrm{T}}$, C. canadensis CECT $5385^{\mathrm{T}}$, C. israelensis CECT $5287^{\mathrm{T}}$, C. sarecensis CCUG $47987^{\mathrm{T}}$, Halomonas elongata ATCC $33173^{\mathrm{T}}$, Halomonas halophila DSM $4770^{\mathrm{T}}$, Halomonas halmophila ATCC $19717^{\mathrm{T}}$, Halomonas venusta DSM $4743^{\mathrm{T}}$, Halomonas pacifica DSM $4742^{\mathrm{T}}$, Halomonas salina ATCC $49509^{\mathrm{T}}$ and Halomonas eurihalina ATCC $49336^{\mathrm{T}}$. MH complex medium was used as the maintenance medium for halophilic strains. This medium contained $\left(\mathrm{l}^{-1}\right)$ $10 \mathrm{~g}$ yeast extract (Difco), $5 \mathrm{~g}$ proteose peptone no. 3 (Difco) and $1 \mathrm{~g}$ glucose (Ventosa et al., 1982) and it was supplemented with a balanced mixture of sea salts (Subov, 1931) to give an adequate salts concentration for growth of marine and moderately halophilic strains. The medium was solidified with $20 \mathrm{~g}$ Bacto agar (Difco) $\mathrm{l}^{-1}$ and the $\mathrm{pH}$ was adjusted to $7 \cdot 2$ with $1 \mathrm{M} \mathrm{NaOH}$.

One hundred and nineteen phenotypic characters including morphological, physiological, biochemical, nutritional and antimicrobial susceptibility tests were determined for each strain. Details of the procedures have been described previously (Prado et al., 1991). The results from the 52 strains and the data for reference strains were coded in a binary form ( 0 , negative; 1 positive; 9 , missing or non-comparable data). Strain similarities were estimated by simple matching coefficients $\left(S_{\mathrm{SM}}\right)$ (Sokal \& Michener, 1958) and clustered by the unweighted pair-group method of association (UPGMA) (Sneath \& Sokal, 1973). Cophenetic correlation was also obtained for each method. The test error was estimated by examining 10 strains in duplicate. The computation was performed by the MINT program using an Eclipse model MV/10000 computer at the Computer Centre, University of Granada.

The colonial morphology and pigmentation of strain LTS$4 \mathrm{~N}^{\mathrm{T}}$, which was chosen as a representative of the group, were observed in mid-exponential phase cultures $(20 \mathrm{~h})$ and old cultures ( 3 days) grown on solid MH medium supplemented with $7 \cdot 5 \%(\mathrm{w} / \mathrm{v})$ total salts. The optimal salts concentration for growth of strain LST- $4 \mathrm{~N}^{\mathrm{T}}$ was determined at different incubation temperatures. The strain was cultured in $\mathrm{MH}$ medium containing the following concentrations of a balanced mixture of sea salts (Subov, 1931): 0, 0.5, 3, 5, $7 \cdot 5,10,15,20$ and $25 \%(\mathrm{w} / \mathrm{v})$. Each $50 \mathrm{ml}$ batch of medium was inoculated with $0 \cdot 1 \mathrm{ml}$ (approx. $10^{5}$ cells $\mathrm{ml}^{-1}$ ) from an appropriate dilution of a $20 \mathrm{~h}$ culture of the microorganism grown in $\mathrm{MH}$ medium containing $7 \cdot 5 \%(\mathrm{w} / \mathrm{v})$ salts. The cultures were incubated at $15,22,32$ or $42^{\circ} \mathrm{C}$ in a rotary shaker. Viable cells were determined from plate counts on solid $\mathrm{MH}$ medium at the appropriate salt concentration. Experiments were performed in triplicate.

Transmission electron microscopy and scanning electron microscopy were used for morphological studies of cells from a $20 \mathrm{~h}$ culture of strain LST- $4 \mathrm{~N}^{\mathrm{T}}$ grown on the surface of $\mathrm{MH}$ agar plates covered with $\mathrm{MH}$ liquid medium (7.5\% $\mathrm{w} / \mathrm{v}$ total salts). Cells for transmission electron microscopy were stained with $2 \%(\mathrm{w} / \mathrm{v})$ phosphotungstic acid and observed by using a Zeiss model EM 902 transmission electron microscope. Samples for scanning electron microscopy were fixed in $2 \%(\mathrm{v} / \mathrm{v})$ glutaraldehyde solution ( $\mathrm{pH} 7 \cdot 2$ ), dehydrated in an acetone series, critical-pointdried, coated with gold and scanned in a Zeiss model DSM950 scanning electron microscope.

The DNA was isolated and purified by the method of Lind \& Ursing (1986). The DNA G $+C$ content was determined by the thermal denaturation method $\left(T_{\mathrm{m}}\right)$ (Marmur \& Doty, 1962) with a Perkin Elmer Lambda 3B spectrophotometer fitted with a temperature program accessory. DNA-DNA hybridization studies were performed by the non-radioactive method described by Ziemke et al. (1998). Reference DNA was double-labelled using DIG-11-dUTP and biotin-16dUTP (Boehringer Mannheim). The labelling was carried out using the Boehringer Mannheim nick-translation kit. The fragment of the 16S rRNA gene was obtained from purified genomic DNA by direct PCR amplification. Primers 16F27 (5'-AGAGTTTGATCMTGGCTC-3') and 16R1525 (5'-AAGGAGGTGWTCCARCC- $3^{\prime}$ ) were used for amplification and the sequencing primers used were 16F357, 16R519 and 16F945 (Fox et al., 1992). The oligonucleotides were produced by Pharmacia Biotech and were then diluted to $100 \mathrm{pmol}^{\mathrm{l}} \mathrm{l}^{-1}$. The PCR was performed in a thermal cycler (480 model; Perkin Elmer) with 30 cycles of 1 min denaturation at $94{ }^{\circ} \mathrm{C}$, followed by $1 \mathrm{~min}$ annealing at $55^{\circ} \mathrm{C}$ and 2 min elongation at $72{ }^{\circ} \mathrm{C}$. The reaction mixture in a total volume of $100 \mu \mathrm{l}$ contained $2 \mu \mathrm{l}$ genomic DNA, $10 \mu \mathrm{l}$ buffer $(100 \mathrm{mM}$ Tris/HCl, pH 8.3, $500 \mathrm{mM} \mathrm{KCl}$; Perkin Elmer), $4 \mu \mathrm{l} \mathrm{MgCl}_{2}$ (25 mM; Perkin Elmer), $1 \mu \mathrm{l} \mathrm{dNTP}$ mixture (dATP, dCTP, dGTP and dTTP each at $10 \mathrm{mM}$; Ultrapure dNTPs set from Pharmacia Biotech) and $1 \mu \mathrm{l}$ Taq DNA polymerase (AmpliTaq DNA polymerase; Perkin Elmer). Each primer was used at a concentration of $20 \mathrm{pmol} \mu \mathrm{l}^{-1}$. PCR products were analysed by electrophoresis in $1.7 \%$ agarose gels in TAE buffer, using a phage $\lambda$ PstI digest as the size marker. The products were purified with Microcon 100 concentrators (Amicon). Purified PCR products were sequenced directly using a Applied Biosystems ABI 373 Stretch DNA sequencer and the manufacturer's protocols for AmpliTaq ${ }^{\mathrm{r}}$ FS with fluorescent dye-labelled 
dideoxynucleotides (ABI PRISM BigDye terminator cycle sequencing ready reaction kit; Perkin-Elmer). The sequences were analysed with ABI PRISM $373 \mathrm{xl}$ Collection 2.0 and Sequencing Analysis 3.3 programs for Macintosh G3.

The sequence obtained was compared with other publicly available 16S rRNA gene sequences deposited in the EMBL database. The sequences were aligned by using CLUSTAL $\mathrm{W}$ 1.8 (Thompson et al., 1994). Phylogenetic trees were constructed by the neighbour-joining method with the MEGA3 program package (Kumar et al., 2004).

The 52 strains isolated from the Atacama saltern clustered in a single phenon at $83 \%$ similarity. The cophenetic correlation value was $0.94 \%$, and the estimated test error was less than $3 \%$. None of the reference strains clustered with the environmental isolates. Phenotypically, the strains studied constitute a homogeneous group. Strain LTS- $4 \mathrm{~N}^{\mathrm{T}}$ was selected as the type strain and representative of the 52 isolates.

Table 1 provides a comparison of the taxonomic features of strain LTS- $4 \mathrm{~N}^{\mathrm{T}}$ with other Chromohalobacter species. Cells were Gram-negative rods, $2 \cdot 3-4 \cdot 2 \times 0 \cdot 35-0.5 \mu \mathrm{m}$. They were motile by means of subpolar flagella. No spores were observed. Colonies of all strains on $\mathrm{MH}$ medium containing $7 \cdot 5 \%(\mathrm{w} / \mathrm{v})$ salts were circular with entire margins, convex, smooth and characteristically black-pigmented. On liquid medium, all the strains produced a brown, diffusible pigment. Optimum growth of strain LTS- $4 \mathrm{~N}^{\mathrm{T}}$ was at a concentration of $7 \cdot 5 \%$ total salts in $\mathrm{MH}$ complex medium, at $\mathrm{pH} 7 \cdot 5$ and $32^{\circ} \mathrm{C}$. The range of total salts concentration in which the bacterium grew at $32{ }^{\circ} \mathrm{C}$ was $0.5-25 \%(\mathrm{w} / \mathrm{v})$. At $15^{\circ} \mathrm{C}$, the micro-organism grew in the balanced mixture of sea salts (Subov, 1931) at concentrations between 0.5 and $20 \%(\mathrm{w} / \mathrm{v}$ ) and $7 \cdot 5 \%$ salts was optimal for growth; however, the strain only grew in a total salts concentration of $0 \cdot 5-15 \%(\mathrm{w} / \mathrm{v})$ when it was incubated al $42{ }^{\circ} \mathrm{C}$ and it grew optimally at $5 \%$ total salts $(\mathrm{w} / \mathrm{v})$ at this temperature.

A nearly complete $16 \mathrm{~S}$ rRNA gene sequence was obtained for strain LTS- $4 \mathrm{~N}^{\mathrm{T}}$ and comparative analysis of the sequence confirmed the affiliation of this strain to the genus Chromohalobacter, with the highest value of $98.3 \%$ sequence similarity. The phylogenetic tree showed that strain LTS- $4 \mathrm{~N}^{\mathrm{T}}$ exhibited the closest phylogenetic affinity to the Chromohalobacter cluster (Fig. 1). The DNA G $+\mathrm{C}$ content in strain LTS- $4 \mathrm{~N}^{\mathrm{T}}$ was $59 \cdot 8 \mathrm{~mol} \%$ (determined by $T_{\mathrm{m}}$ method). DNADNA hybridization experiments between strain LTS- $4 \mathrm{~N}^{\mathrm{T}}$ and previously described species of Chromohalobacter showed values of DNA-DNA relatedness of $48 \cdot 7,56 \cdot 1,40 \cdot 9,51 \cdot 4$ and $56.9 \%$ with C. marismortui ATCC $17056^{\mathrm{T}}$, C. canadensis CECT $5385^{\mathrm{T}}$, C. israelensis CECT $5287^{\mathrm{T}}$, C. salexigens CECT $5384^{\mathrm{T}}$ and C. sarecensis CCUG $47987^{\mathrm{T}}$, respectively.

On the basis of morphological, phenotypic and genotypic data, we propose that strain LST- $4 \mathrm{~N}^{\mathrm{T}}$ should be classified as representing a novel species within the genus Chromohalobacter, Chromohalobacter nigrandesensis sp. nov.

Table 1. Differential characteristics of strain LTS- $4 N^{\top}$ and other Chromohalobacter species

Data were taken from Arahal et al. (2001a, b, 2002), Quillaguamán et al. (2004) and this study. Characters are scored as: +, positive; -, negative; ND, not determined; d, differs among studies.

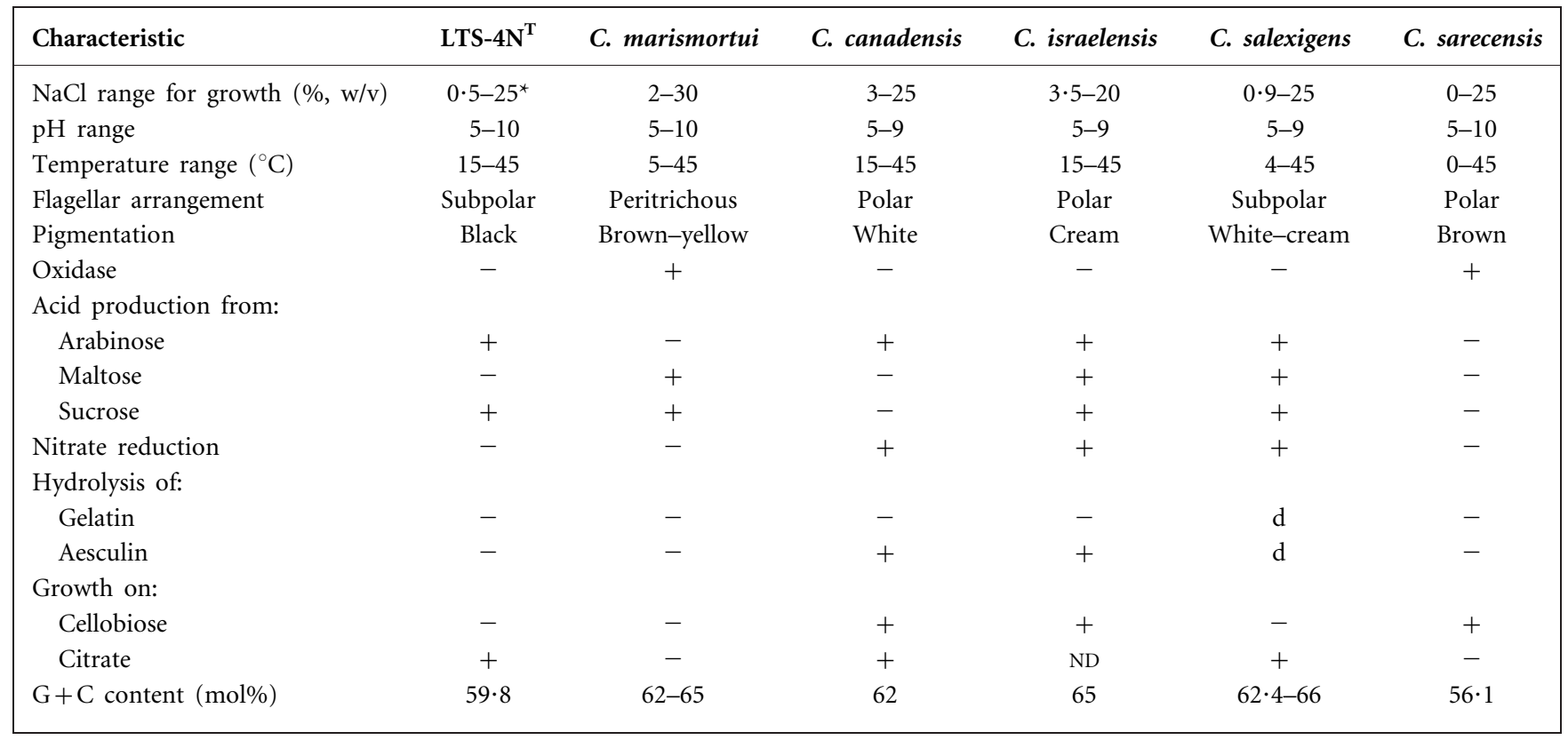

${ }^{\star}$ Total salts (refer to the balanced mixture of sea salts of Subov, 1931). 


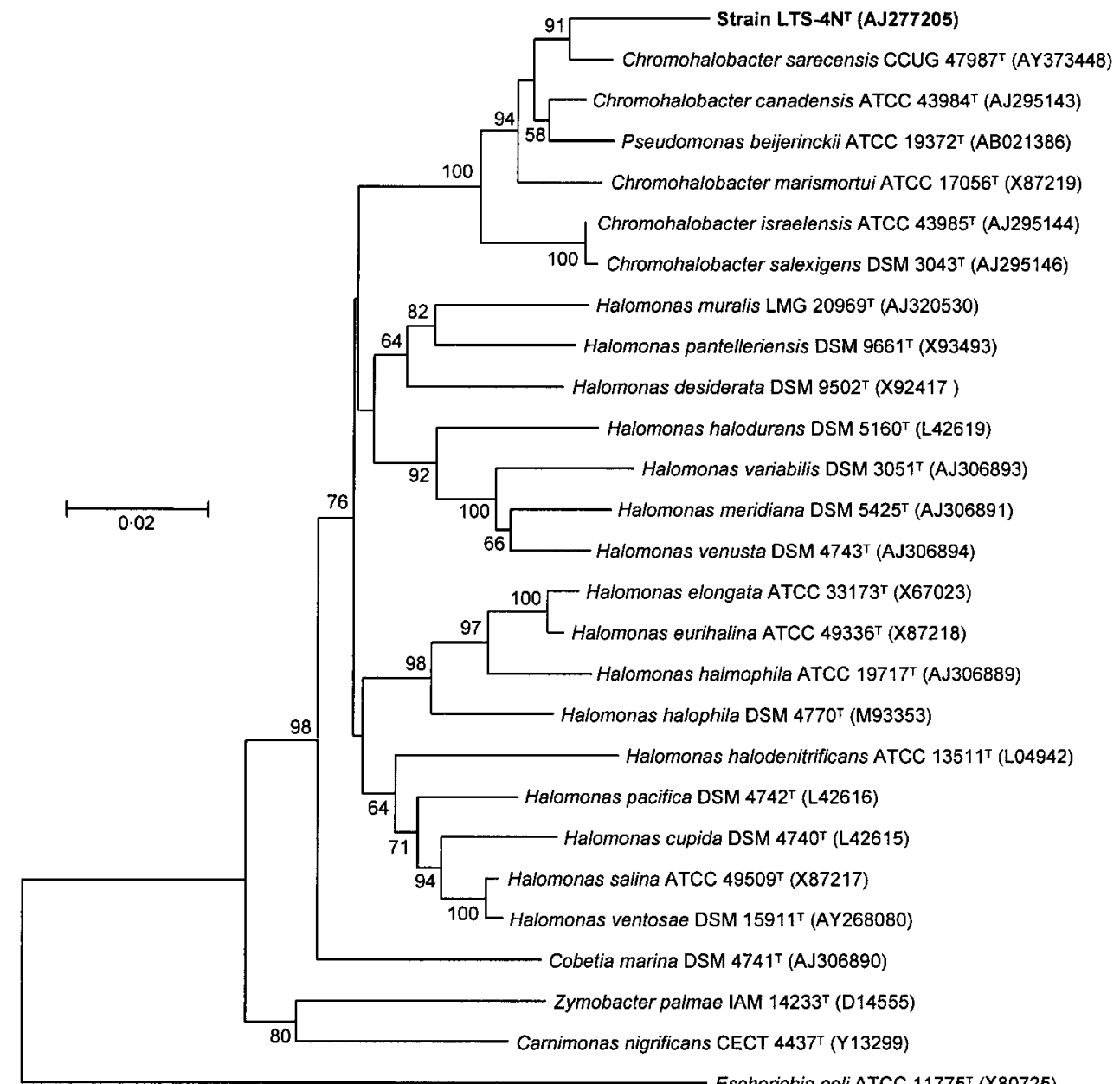

Escherichia coli ATCC 11775' (X80725)

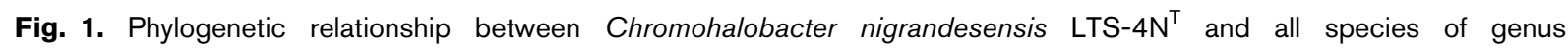
Chromohalobacter, several species of the genus Halomonas and related species Pseudomonas beijerinckii, Zymobacter palmae, Cobetia marina and Carnimonas nigrificans. The tree was constructed using the neighbour-joining algorithm based on 16S rRNA gene sequences. GenBank accession numbers used in the phylogenetic analysis are given in parentheses. Escherichia coli ATCC $11775^{\top}$ was taken as the outgroup. Only bootstrap values greater than $50 \%$ are shown (1000 replications). Bar, 0.02 substitutions per nucleotide position.

\section{Description of Chromohalobacter nigrandesensis sp. nov.}

Chromohalobacter nigrandesensis (nig.ran.des.en'sis. L. adj. niger black; N.L. masc. adj. andesensis pertaining to the Andes; N.L. masc. adj. nigrandesensis relating to the black pigment and to the Andes, the mountain range of Chile).

Cells are Gram-negative, straight or sometimes slightly curved rods, $2 \cdot 3-4 \cdot 2 \times 0 \cdot 35-0 \cdot 5 \mu \mathrm{m}$. Motile by means of subpolar flagella. Non-spore-forming. Colonies are circular, black and very mucous in complex solid medium containing $7 \cdot 5 \%$ $(\mathrm{w} / \mathrm{v})$ total salts. Catalase-positive and oxidase-negative. Chemo-organotrophic. Growth occurs in media containing $0 \cdot 5-25 \%(\mathrm{w} / \mathrm{v})$ total salts and optimal growth occurs at $7 \cdot 5 \%(\mathrm{w} / \mathrm{v})$ total salts. The $\mathrm{pH}$ range for growth is 5 to 10 . The optimal temperature for growth is $32{ }^{\circ} \mathrm{C}$. Tween 20 is hydrolysed. Citrate-positive. Nitrate is not reduced. Arginine dihydrolase-positive. Urease-positive. $\mathrm{H}_{2} \mathrm{~S}$ is produced from L-cysteine. Acids are produced from various sugars (arabinose, xylose, fructose, galactose, glucose and sucrose). A great variety of organic compounds, including arabinose, fructose, galactose, glucose, inulin, maltose, mannose, sucrose, trehalose, xylose, acetate, fumarate, gluconate, lactate, malate, pyruvate, succinate, glycerol and mannitol, are used as sole carbon and energy sources. The following compounds are utilized as sole carbon, nitrogen and energy sources: alanine, arginine, asparagine, aspartate, glutamate, ornithine and serine. Susceptible to ampicillin, chloramphenicol, erythromycin, penicillin $\mathrm{G}$ and rifampicin and resistant to tetracycline. The $\mathrm{G}+\mathrm{C}$ content of the DNA of the type strain is $59.8 \mathrm{~mol} \%\left(T_{\mathrm{m}}\right)$.

The type strain is LST $-4 \mathrm{~N}^{\mathrm{T}}\left(=\operatorname{CECT} 5315^{\mathrm{T}}=\mathrm{DSM} 14323^{\mathrm{T}}\right.$ ), isolated from hypersaline Lake Tebenquiche in the Atacama Saltern, Chile. 


\section{Acknowledgements}

This study was supported, in part, by grants from the Junta de Andalucía (project CVI 190), Spain, the Volkswagen Stiftung (project 1/64.465), Germany, and DGI-UCV, Chile.

\section{References}

Arahal, D. R., García, M. T., Ludwig, W., Schleifer, K. H. \& Ventosa, A. (2001a). Transfer of Halomonas canadensis and Halomonas israelensis to the genus Chromohalobacter as Chromohalobacter canadensis comb. nov. and Chromohalobacter israelensis comb. nov. Int J Syst Evol Microbiol 51, 1443-1448.

Arahal, D. R., Garcia, M. T., Vargas, C., Cánovas, D., Nieto, J. J. \& Ventosa, A. (2001b). Chromohalobacter salexigens sp. nov., a moderately halophilic species that includes Halomonas elongata DSM 3043 and ATCC 33174. Int J Syst Evol Microbiol 51, 1457-1462.

Arahal, D. R., Ludwig, W., Schleifer, K. H. \& Ventosa, A. (2002). Phylogeny of the family Halomonadaceae based on $23 \mathrm{~S}$ and $16 \mathrm{~S}$ rDNA sequence analyses. Int J Syst Evol Microbiol 52, 241-249.

Elazari-Volcani, B. (1940). Studies on the microflora of the Dead Sea. $\mathrm{PhD}$ thesis, Hebrew University, Jerusalem, Israel.

Fox, G. E., Wisotzkey, J. D. \& Jurtshuk, P., Jr (1992). How close is close: $16 \mathrm{~S}$ rRNA sequence identity may not be sufficient to guarantee species identity. Int J Syst Bacteriol 42, 166-170.

Kaye, J. Z., Márquez, M. C., Ventosa, A. \& Baross, J. A. (2004). Halomonas neptunia sp. nov., Halomonas sulfidaeris sp. nov., Halomonas axialensis sp. nov. and Halomonas hydrothermalis sp. nov.: halophilic bacteria isolated from deep-sea hydrothermal-vent environments. Int J Syst Evol Microbiol 54, 499-511.

Kumar, S., Tamura, K. \& Nei, M. (2004). MEGA3: integrated software for Molecular Evolutionary Genetics Analysis and sequence alignment. Brief Bioinform 5, 150-163.

Lind, E. \& Ursing, J. (1986). Clinical strains of Enterobacter agglomerans (synonyms: Erwinia herbicola, Erwinia milletiae) identified by DNA-DNA hybridization. Acta Pathol Microbiol Immunol Scand Sect B Microbiol 94, 205-213.

Marmur, J. \& Doty, P. (1962). Determination of the base composition of deoxyribonucleic acid from its thermal denaturation temperature. J Mol Biol 5, 109-118.
Oren, A. (2002). Diversity of halophilic microorganisms: environments, phylogeny, physiology, and applications. J Ind Microbiol Biotechnol 28, 56-63.

Prado, B., Del Moral, A., Quesada, E., Ríos, R., Monteoliva-Sanchez, M., Campos, V. \& Ramos-Cormenzana, A. (1991). Numerical taxonomy of moderately halophilic Gram negative rods isolated from the Salar of Atacama, Chile. Syst Appl Microbiol 14, 275-281.

Quillaguamán, J., Delgado, O., Mattiasson, B. \& Hatti-Kaul, R. (2004). Chromohalobacter sarecensis sp. nov., a psychrotolerant moderate halophile isolated from the saline Andean region of Bolivia. Int J Syst Evol Microbiol 54, 1921-1926.

Rodriguez-Valera, F. (1988). Characteristics and microbial ecology of hypersaline environments. In Halophilic Bacteria, vol. 1, pp. 3-30. Edited by F. Rodriguez-Valera. Boca Raton, FL: CRC Press.

Sneath, P. H. A. \& Sokal, R. R. (1973). Numerical Taxonomy. The Principles and Practice of Numerical Classification. San Francisco: W. H. Freeman.

Sokal, R. R. \& Michener, C. D. (1958). A statistical method for evaluating systematic relationships. Univ Kansas Sci Bull 38, 1409-1438.

Subov, N. N. (1931). Oceanographical Tables. Moscow: USSR Oceanographic Institute Hydrometeorological Commission (in Russian).

Thompson, J. D., Higgins, D. G. \& Gibson, T. J. (1994). CLUSTAL W: improving the sensitivity of progressive multiple sequence alignment through sequence weighting, position-specific gap penalties and weight matrix choice. Nucleic Acids Res 22, 4673-4680.

Ventosa, A., Quesada, E., Rodriguez-Valera, R., Ruiz-Berraquero, F. \& Ramos-Cormenzana, A. (1982). Numerical taxonomy of moderately Gram-negative rods. J Gen Microbiol 128, 1959-1968.

Ventosa, A., Gutierrez, M. C., Garcia, M. T. \& Ruiz-Berraquero, F. (1989). Classification of "Chromobacterium marismortul" in a new genus, Chromohalobacter gen. nov., as Chromohalobacter marismortui comb. nov., nom. rev. Int J Syst Bacteriol 39, 382-386.

Ventosa, A., Nieto, J. J. \& Oren, A. (1998). Biology of moderately halophilic aerobic bacteria. Microbiol Mol Biol Rev 62, 504-544.

Ziemke, F., Höfle, M. G., Lalucat, J. \& Rosselló-Mora, R. (1998). Reclassification of Shewanella putrefaciens Owen's genomic group II as Shewanella baltica sp. nov. Int J Syst Bacteriol 48, 179-186. 